\title{
Flow-carried and active swimming migration of the glass eel (Anguilla anguilla) in the tidal area of a small estuary on the French Atlantic coast
}

\author{
Didier Gascuel \\ Laboratoire de Biologie Halieutique de l'ENSAR - ERA/IFREMER \\ 65 route de St Brieuc, 35042 Rennes Cedex, France
}

\begin{abstract}
The study of the migration dynamics of glass eels (Anguilla anguilla) in a small estuary of the French Atlantic coast shows a two-stage sequence: (1) From November to March, the glass eels migrate upstream by using the tidal currents. The estuarine hydrology leads to a natural trapping of migrants in a typical area where the current speed slows down. The location of this zone depends on hydraulic conditions. The greater the tide is the farther upstream this area will be. This phenomenon leads to an increasing catchability of elvers. (2) From April onwards, when the water temperature reaches $10-12^{\circ} \mathrm{C}$, the glass eels swim actively upstream in the estuary. Then, fish concentrate just below the first dam. This behaviour shift shows the beginning of the colonization process of the whole riverine system.
\end{abstract}

\section{INTRODUCTION}

From November 1981 to April 1984, the migration of glass eel was studied in a small estuary on the French Atlantic coast: the Sevre Niortaise ( $16 \mathrm{~km}$ long, 40 to $200 \mathrm{~m}$ wide). No saline waters flow into this estuary during the whole migration period. However, the flood tide reaches the upstream end of the estuary, which is locked by a dam at every flood tide. Therefore, the data obtained concern the tidal freshwater part of the glass eel migration.

\section{STUDY METHODS}

The study of the distribution and movements of glass eels is based upon several series of observations (Gascuel, 1986).

(a) Creel census of commercial fishermen. Commercial fishery in the estuary is allowed from 15 October to $31 \mathrm{March}$. About 60 fishermen work with tow-nets $\left(1.5 \mathrm{~m}^{2}\right.$ section, $0.8 \mathrm{~mm}$ mesh size). Special logbooks from about 10 fishermen (1981-82 and 1982-83 fishing season) allow us to follow the daily trends of the CPUE (catch per fishing trip) in different parts of the estuary ( 4 sectors were determined). These CPUE have been considered firstly as an abundance index of glass eels.

(b) Sampling in the estuary. Samples of glass eels were collected during commercial fishing trips and from a plankton net $\left(0.4 \mathrm{~m}^{2}\right.$ section, $0.8 \mathrm{~mm}$ mesh size) towed by a small craft. The sampling was planned to follow daily and seasonal trends of density through- 
out a tidal cycle and between several cycles. In 1982 and 1983, 141 samples were taken on a monthly basis during 18 months in the upstream and 12 months in the downstream part.

(c) Sampling just below the dam. By hand pulling a plankton net from the bank, samples were collected just below the dam from December 1981 to May 1982.

(d) Mark/Recapture. Two experiments of mark/recapture by using dyes (Neutral red, Bismarck Brown; Cantrelle, 1981) were made. Five and nine $\mathrm{kg}$ of coloured glass eels were released in the downstream part of the estuary, in February 1983 and in March 1984 respectively. Recaptures in every sector were observed by commercial fishermen during the days following.

All these observations were combined with a hydrological study of the estuary to assess how the water masses move according to the tidal cycle, freshwater flow tide strength (Gascuel, 1986). From this a two-stage migration behaviour of glass eel was determined: a flow-carried migration and an active swimming migration.

\section{FLOW-CARRIED MIGRATION STAGE}

The behaviour of glass eels in tidal currents is well known (Creutzberg, 1958). During ebb tide, they hide in the sediment or swim very close to the ground*. On the flowing tide, they move upwards through the water column, more often at night. At each tidal cycle, this behaviour leads to an upstream movement of glass eels. Then, the tidal currents have to be considered as transfer vectors.

Analysis of our data, obtained in the estuary of the Sevre Niortaise from November to the end of March, shows that all the movements of glass eels are due mainly to this behaviour. When they move upwards, they do not swim in any definite direction. They depend strongly on transits of the water masses. This stage is called the flow-carried migration stage.

Three observations can confirm this behaviour:

(a) Mark/recapture experiments. The distances covered by the coloured glass eels are smaller than or equal to those covered by the water masses during the flood tide following the time of release. Only some individuals seem to move faster than by using the currents, but their swimming speed seems very low (probably $<0.1 \mathrm{~m} \mathrm{~s}^{-1}$ ). On the other hand, most of the animals do not avail of the full theoretical capacities of the currents to move. This fact might be associated with a merely partial upward moving when the flood tide occurs. Some of them stay very close to the bottom during all or nearly all the flood tide, particularly during daylight tides.

(b) No accumulation below the dam. During this migration period, the densities of glass eels just below the dam and downstream in the estuary are very similar (1 to 2 glass eels $\mathrm{m}^{-3}$ at high water). The dam cannot be considered as a physical obstacle to migration. It only prevents the actively swimming glass eels from passing onwards. Nevertheless, it indirectly intervenes by slowing down the flood tide current in all the upstream part of the estuary.

\footnotetext{
* As in the freshwater tidal part of the Penobscot estuary (McCleave \& Kleckner, 1982), total hiding can be observed in the estuary of the Sevre Niortaise. Indeed, no individual was caught there at ebb tide, when using pelagic samplers.
} 
(c) Influence of hydrodynamical factors on the distribution of glass eels. More generally, the flow-carried migration behaviour is highlighted by studying the distribution of the glass eels, which is closely related to the hydrodynamics. At flood tide, the upstream distance covered by the water masses decreases the farther upstream you go (Fig. 1). At the same time, maximal densities are observed in the area where the flood current slows down. Hence, the estuarine hydrodynamics involves a natural trapping of animals in an area the location of which depends on the freshwater flow and the tide strength.

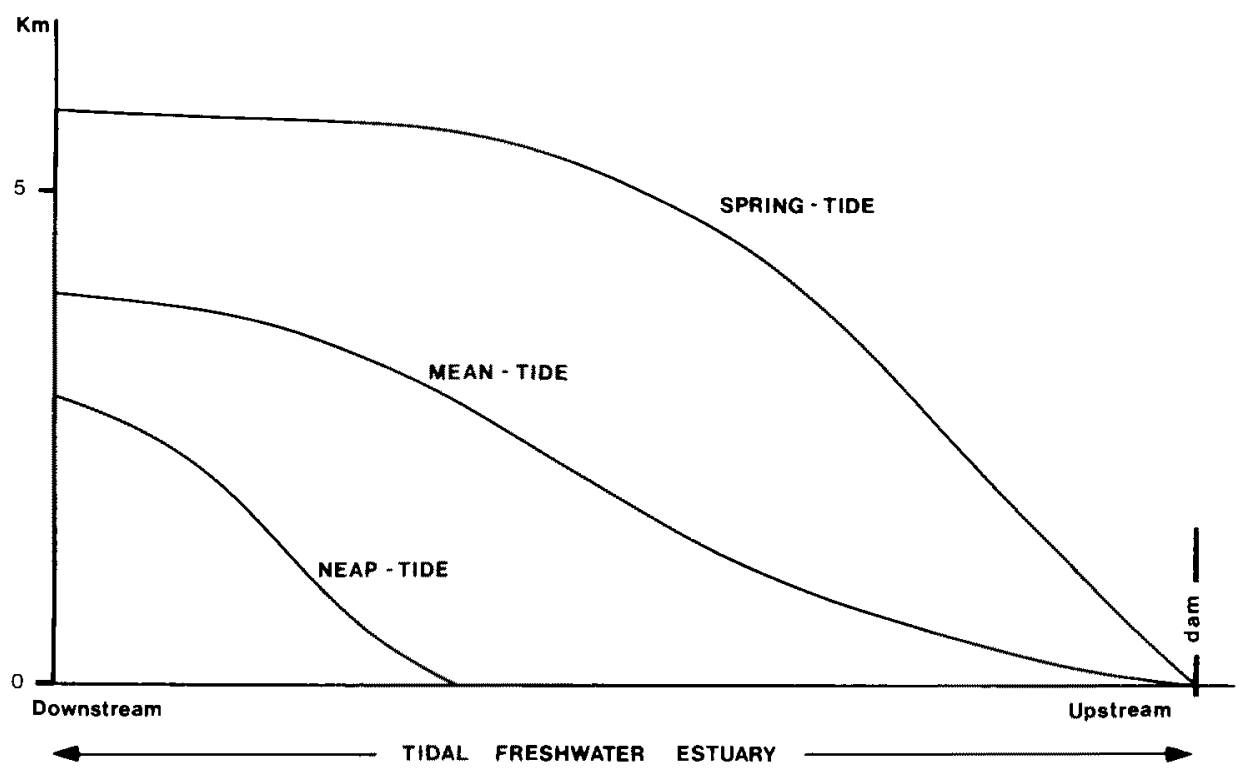

Fig. 1. Estimation of distances covered by the flood-tide current during average flood conditions

As the tidal strength grows together with constant river flows, the further upstream this trapping area moves. During neap tides, the maximal densities have been found in the lower part of the estuary, while during the flood tide they were located in upper parts (Fig. 2). At the same time, the fishing effort moves as well, which corresponds to an empirical adaptation of the population of fishermen to the distribution of the glass eels.

Furthermore, when the tidal strength increases and the trapping area moves upstream, the densities at high tide increase as well (Fig. 2). At the beginning of the flood tide, the fish are distributed in a smaller water volume than the water volume which they left before, at the beginning of the previous ebb tide (Fig. 3). Then, while they move upstream, their density and their subsequent catchability increase in a lower water volume. Thus, the estuarine hydrodynamics leads to a progressive concentration of glass eels. This concentration is higher as the ratio volume at high water / volume at low water, and consequently the tide strength are higher. 


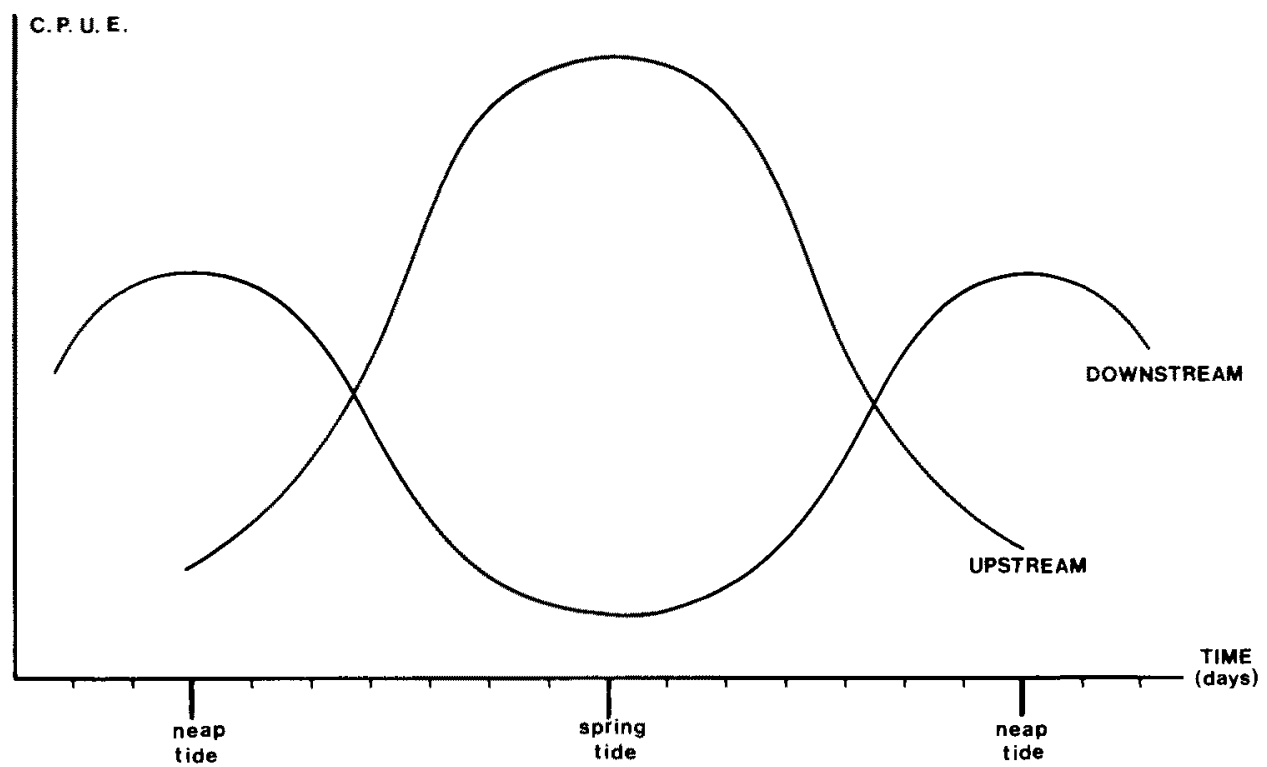

Fig. 2. Theoretical daily variations of glass eel density at high water, in the upstream and downstream parts of the estuary

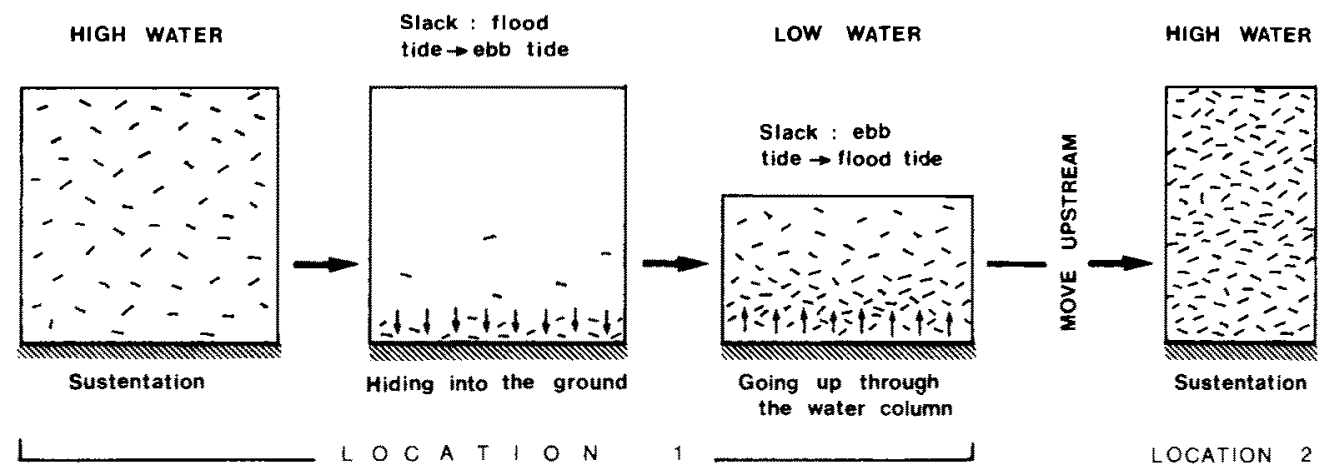

Fig. 3. A consequence of the flow-carried behaviour: the concentration of glass eels at each tidal cycle

\section{ACTIVE SWIMMING MIGRATION STAGE}

Each year (1982 and 1983) from April a change in the migratory behaviour of glass eels is observed. An active swimming migration adds to the flow-carried migration. While they move up the water column the glass eels swim upstream.

Hence they aggregate just below the dam. At high water, densities are about 30 times the downstream ones ( $30 \mathrm{vs} 1$ glass eel per $\mathrm{m}^{3}$ ). More generally, the hydrodynamical factors can no longer explain the glass eel distribution in the estuary. From that time onwards, the densities remain very low in downstream parts, whatever the estuarine 
conditions may be. At the same time, significant runs of glass-eels are recorded on the elver-ladder built in 1984 at the dam (Bertignac, 1984). To ascend this device the glass eels have to swim against the current, which they could not do before during winter time.

As this behaviour is developing, the depth distribution of the glass eels changes too during the flood tide: the densities are higher in upper layers of water than near the bottom. Such an observation has also been made in other estuaries, such as the Loire (Elie, 1979) and Gironde (Cantrelle, 1981).

Water temperature seems to be a major factor in releasing this active swimming migration. Indeed, the temperature of estuarine waters increases very quickly during April $\left(9^{\circ} \mathrm{C}\right.$ to $\left.12-15^{\circ} \mathrm{C}\right)$. This temperature increment is found to be related to the eel aggregation just below the dam. Likewise, Bertignac (1984) observed good elver runs on the ladder when temperature exceeds $14^{\circ} \mathrm{C}$. A number of authors already reported the influence of this abiotic factor on the glass eel migration in upper parts of estuaries or in river systems (in Tesch, 1977). We can note that active migration seems to be initiated by water temperatures higher than $10-12^{\circ} \mathrm{C}$.

\section{DISCUSSION}

During winter time, the huge river flows involve a very asymmetrical tidal curve. At flood tide, the water masses move between 4 and $7 \mathrm{~km}$ in the lower parts of the estuary. At low tide they vary from 10 to $30 \mathrm{~km}$ depending upon the river flow and the tide strength. Thus, by hiding in the sediment at ebb tide, the glass eels seem to display a very good adaptation to the environment. Indeed not only does it enable them to stay at the same spot, but also to move upstream with a very low energetic cost. The latter seems to be all the lower as the flow-carried behaviour involves no precise orientation when the glass eels move upwards from the sediment.

This behaviour seems to succeed to the resting stage in brackish waters of estuaries (Deelder, 1958). During this stage, the hiding of the animals in the sediment is incomplete (McCleave \& Kleckner, 1982; Elie, 1979); at each tide, they partially move forward and back.

Upstream of the tidal area, the moving forward of the glass eels involves an active swimming behaviour. The final orientation is to reach the upper parts. Of course, these ethological variations gradually develop at individual and population scale; they can be observed earlier or not, depending on the year. They still constitute stages of the upstream eel migration. Indeed, the active swimming migration can be considered as the first step of the colonization of the river system. In the lower parts of the Sevre-Niortaise system, the migration of glass eels and elvers mainly occurs from April to June (Gascuel, 1986). The several months shift between the modal migration through the estuary (November to April) and through the river system (from April onwards) seems to be a consequence of the succession of both the stages: flow-carried and active swimming migration.

In a stock management scheme, this shift phenomenon involves two consequences:

(a) From November to March, few glass eels emigrate from the estuary to the upper parts. The fishing mortality may be considered as an essential factor of the migration dynamics; it compensates the new immigration runs of glass eels from the sea to a great extent. 
(b) When it is analyzed by the CPUE of commercial fishermen, the abundance of glass eels is only one of the elements which determine the annual recruitment in the river system. The latter occurs when the fishing season is closed (end of March),

To know the conditions of glass eel migration through the estuary enables us to assess the runs. Thus, it will be possible to analyze the influence of anthropical factors over the fraction of the eel stock which goes into the watershed area.

Acknowledgements. This study has been financially supported by the Regional Natural Park of "Marais Poitevin".

\section{LITERATURE CITED}

Bertignac, M., 1984. Etude d'une passe à civelles et des manoeuvres d'ouvrages à la mer. Rapport contrat Parc Naturel Régional du Marais Poitevin. Laboratoire de Biologie Halieutique de l'ENSA de Rennes, 80 pp.

Cantrelle, I., 1981. Etude de la migration et de la pêche des civelles (Anguilla anguilla L.) dans l'estuaire de la Gironde. Thèse, Univ. Paris, $237 \mathrm{pp}$.

Creutzberg, F., 1958. Use of tidal streams by migrating elvers (Anguilla vulgaris Turt.). - Nature, Lond. 22, 857-858.

Deelder, C. L., 1958. On the behaviour of elvers (Anguilla vulgaris Turt.) migrating from the sea into freshwater. - J. Cons. perm. int. Explor. Mer 24, 135-146.

Elie, P., 1979. Contribution à l'étude des montées de civelles d'Anguilla anguilla L. dans l'estuaire de la Loire: Pêche, écologie, écophysiologie et élevage. Thèse, Univ. Rennes, $381 \mathrm{pp}$.

Gascuel, D., 1986. La civelle d'anguille dans l'estuaire de la Sèvre Niortaise: biologie, écologie, exploitation. Rapport contrat Parc Naturel Régional du Marais Poitevin. Laboratoire de Biologie Halieutique de l'ENSA de Rennes, 220 pp.

McCleave, J. D. \& Kleckner, R. C., 1982. Selective tidal stream transport in the estuarine migration of glass eels of American eel (Anguilla rostrata). - J. Cons. perm. int. Explor. Mer 40, 262-271.

Tesch, F. W., 1977. The eel. Chapman \& Hall, London, $434 \mathrm{pp}$. 